ARTICLE

DOI: $10.1057 /$ s41599-018-0084-x

\title{
Family obligations across European borders: negotiating migration decisions within the families of post-accession migrants in Sweden
}

\author{
Oksana Shmulyar Gréen ${ }^{1} \&$ Charlotte Melander ${ }^{2}$
}

\begin{abstract}
The negotiation of migration decisions within the families of post-accession mobile workers from Poland and Romania in Sweden is explored through the concept of family obligations. This study departs from Finch's (1987) and Mason's (1996) seminal works, which identified a wide range of supportive (and non-supportive) exchanges and negotiated commitments within families and their kin. Drawing on Mason's (1996) definition of care as both sentient activity and active sensibility, we seek to understand how migrant parents negotiate their migration decisions as an act of care and responsibility, but also as morally imbued obligations in relation to their children. As an analytical tool, the lifeline method (Davies, 1996) is used to capture key moments and events shaping the migration decisions of European workers' families, which include their motivations to pursue migration, the gendered patterns of care shaping their migration decisions, and moral reasoning over what is the right thing to do in relation to caring for their children. The analysis shows that mobile families' decisions to migrate are 'livelihood strategies' involving complex and dynamic negotiations over the options and resources of entire families and their kin across generations and transnational locations. While reflecting on their decisions over time, both migrant parents express their genuine involvement in caring responsibilities. However, the actual practice shows that caring is still a gendered activity. Finally, the decision to migrate shows that migration itself can be seen as an act of relational and emotional caring involving moral reasoning, feelings and thoughts through which migrant parents negotiate their "good parenthood".
\end{abstract}

\footnotetext{
${ }^{1}$ Sociology and Work Science Department, University of Gothenburg, 40530 Gothenburg, Sweden. ${ }^{2}$ Department of Social Work, University of Gothenburg, 40530 Gothenburg, Sweden. Correspondence and requests for materials should be addressed to O.S.G. (email: Oksana.shmulyar@socav.gu.se)
} 


\section{Introduction}

he central question of this article is how do migrant parents negotiate their migration decisions as an act of care and responsibility, but also as morally imbued obligations in relation to their children, with a particular focus on the negotiations of migration decisions within the families of postaccession mobile workers from Poland and Romania in Sweden. ${ }^{1}$ Our approach to what constitutes family obligations stems from Finch's (1987, 1989) and Mason's (1996) seminal works identifying a wide range of supportive (and non-supportive) exchanges within families and their kin as "the manifestations of responsibilities" (Yeandle, 1996, p 508) developing over time with moral, emotional, and material components. Seen from this angle, we seek to shed light on the manifestations of the multiple familiar responsibilities related to care between parents and their younger children in the context of parental labor migration. Theoretically, we draw on the insights from the feminist conceptual framework of family obligations, care and responsibility for others (Finch, 1987, 1989; Mason, 1996), and care and moralities in transnational families in particular (Carling, 2008) in combination with the notion of gendered practices of transnational parenting (Pustulka et al., 2015; Souralová and Fialová, 2017) to address a new empirical context for the contemporary intra-European migration from the new European Union (EU) member states to the Nordic countries, and to Sweden in particular. We focus on mobile workers and their families from two EU countries in Central and Eastern Europe (CEE), i.e., Poland and Romania, which joined the EU in 2004 and 2007, respectively. Following the wider European tendencies, most of the recent arrivals to Sweden and other Nordic countries are from Poland and lately from Romania, which are the two dominant countries of origin among post-accession migrants (Olofsson, 2012; Friberg and Eldring, 2013; Delmi, 2016).

As some scholars have already shown, the issues of transnational families and care are widely researched phenomena (Carling et al., 2012; Baldassar and Merla, 2013; Kilkey and PalengaMöllenbeck, 2016). However, transnational family obligations in relation to children are still significantly understudied in the geographical context of a larger Europe (Ducu and Telegdi-Csetri, 2016), with some exceptions shown in the research on Polish families in the UK, Ireland and Norway (White, 2010; Friberg, 2012; McGhee et al., 2013; Bell and Bivand Erdal, 2015; Slany and Pustulka, 2016; Slany et al., 2018). For example, until very recently, post-accession mobility in Sweden has most commonly been examined in terms of its demographic composition and economic contribution, as well as the effects on income and occupational position of the new EU nationals in the Swedish labor market (Andersson and Hammarstedt, 2011; Friberg and Eldring, 2013; Gerdes and Wadensjö, 2016) or the political consensus in Sweden concerning its open-door policy on EU mobility and labor migration (Berg and Spehar, 2013). This article aims to fill this gap by critically analyzing other important dimensions in relation to the EU mobility by extending studies of the working life of post-accession migrants to include their families and the negotiations of family obligations taking place in a transnational European setting, with Sweden as an empirical case.

Invoking Finch's (1987, p 159) broader conceptualization of family obligations as the "relationship between norms and negotiations", a broader aim for this article is to interrogate how the moral identities of migrant parenthood in relation to care features in migrant parents' decisions to migrate, are negotiated in relation to their own responsibilities, involvement and capacities to provide care to children in a transnational social space. The questions we seek to answer more specifically are: How are parental migration decisions negotiated as livelihood options for the family against the backdrop of the persisting socio-economic inequalities within an expanded EU? How do norms, commitments, thoughts and emotions in relation to care operate in gendered terms when making migration decisions? How do transnational caring obligations evolve around the ideal of "good" parenthood and moral reasoning over the right course of action in relation to care?

To capture the multifaceted aspects of care as one of the central elements in family obligations, we focus our analysis on care arrangements for children in the families where one or both parents migrated to Sweden for work while their children initially remained at home. The existing research conceives of these family constellations as "split households" or "separated nuclear families" (Bell and Bivand Erdal, 2015, p 79), which often regard'living apart together' as primarily a temporary form of transnational family life. Indeed, most of the parents whom we interviewed during the research project have brought their family to settle in Sweden after a period of time because Sweden is usually perceived as a more family friendly, equal and inclusive society (Widding Isaksen, 2010) compared to the crisis-driven and less welfarecommitted post-socialist societies in the EU. However, we intentionally choose to examine these particular family constellations, and more specifically the family's migration decisionmaking processes because it allows us to tease out, e.g., how looking back at their lives as migrants, parents reason about their responsibility to care, as well as how the experiences, thoughts and emotions of leaving, being left and living in an 'open-ended' mobility appear to have inherent moral dimensions.

The main body of this article is divided into four sections. The first section provides a brief overview of the new geographies of mobility in Europe, with Sweden being a newly popular destination for mobile workers from Poland and Romania. The second section presents the theoretical conceptualizations linking the perspective of family obligations with the concepts of care and transnational moralities through a gendered lens. The data and methods are described in more detail in the third section. The fourth section examines family migration decisions involving negotiations of moralities, feelings and thoughts on care over time, with a focus on three aspects: i.e., motive to search for livelihoods abroad, gendered patterns in negotiating transnational care as an option, and the moral dimensions of migration decision-making as measure of "good" parenting. The concluding discussion suggests the possible contribution of the sociological conceptualization of family obligations as sentient activity and active sensibility (Mason, 1996) to the study of caring and support strategies within the transnational families. More specifically, this study illustrates migration decision-making as an essential moral, emotional and relational context in which family obligations and responsibilities develop between migrating parents and their children within the European mobility space.

\section{New geographies of mobility in Europe}

The mobility patterns from Poland and Romania within the EU's free movement space and more specifically in Sweden are overviewed below. In addition, we briefly highlight the differences among the welfare and family policies in these three countries to describe the circumstances in two pairs of contrasting institutional contexts in which individual caring strategies and decisions to migrate are situated. Our respondents originate from Poland and Romania, which are two formerly socialist countries that experienced profound societal transformations during the last 25 years on their evolution from authoritarian and centrally planned economies to democratic and capitalist regimes. One of the most significant features of these transformations has been the increasing propensity to move and seek paid employment in 
other more prosperous European countries (Black et al., 2010; Anghel, 2013; Glorius et al., 2013). Although they share several common socio-economic patterns in their post-socialist journey, Poland and Romania have quite different legacies when it comes to migration.

Poland: From long-lasting migration to mobility and settlement in Europe. Poland was a significant sending country for migrant labor to both Europe and globally long before the collapse of communism. Although the international migration of Poles was carefully guarded by the Polish socialist state, many people crossed its borders, mainly illegally and for a short time, "to accumulate goods and money" (Iglicka, 2000, p 72) to be spent at home. In Poland, as well as in the whole CEE region, migration for work intensified during the 1990s and peaked when the country joined the EU in 2004. The most recent figures on mobility patterns indicate that in the years immediately after the EU accession process (2004-2007), there were 2.3 million temporary migrants from Poland (Fihel et al., 2012, p 80). The propensity to move in search for a job remained stable even after the 2008 economic crisis, with more prolonged stays and greater permanency than in the first few years after the enlargement of the EU (Ryan et al., 2009; Slany and Pustulka, 2016). Several researches attributed this enduring mobility to the unprecedented differences in the living standards within the EU since its enlargement (Perrons et al., 2010; Black et al., 2010). For instance, Dølvik (2013) noted that the nominal wages in the new EU member states ranged from one-tenth to one-seventh of those in the rest of the EU, while the living standards were on average 45 per cent of those in Western Europe prior to accession.

Romania: From coercive control of mobility to unrestricted migration. Migration from Romania was strictly controlled and practically halted by the state before the fall of the Iron Curtain (Anghel, 2013; Andrén and Roman, 2014). Prior to 1989, migrants were mainly political refugees or highly educated Romanians from the ethnic minorities (Jewish or German) who could get permission to leave the country (Andrén and Roman, 2014). One of the most significant features of the failure of communism was the increased opportunities for Romanians and other East and Central Europeans to travel and seek paid employment in the West. Workers from Romania dominated the flow of irregular migrants in southern Europe between 2002 and 2007 (Anghel, 2013). After joining the EU, Romanian nationals still could not enjoy full freedom of movement until 2011 because of the transition rules that were applied to both Romania and Bulgaria upon their EU accession (Fihel et al., 2012; Andrén and Roman, 2014). ${ }^{2}$ Nevertheless, Romanians were among the most mobile Eastern Europeans. In 2009, Romanians comprised six per cent of the whole EU population and were the second largest group among non-nationals in the 27 countries of the EU (Eurostat, 2011).

Poles and Romanians in Sweden. Sweden is one of the few EU countries (together with the United Kingdom ${ }^{3}$ and Ireland) that opened its labor market to workers from the new EU member states after 2004. Poland and Romania were the two largest countries of origin among the EU mobile citizens coming to Sweden (Friberg and Eldring, 2013). Even if Sweden is not a primary destination country for EU workers in general, a considerable number of Poles and Romanians consider it as a possible country where they can search for work (OECD, 2015). The International Organization for Migration estimates that 10 per cent of Poland's total population (37.9 million) resided abroad in 2015; approximately 84,000 were registered as residents in
Sweden (IOM, 2015). Compared to Poland, Romania has a significantly smaller population (19.7 million); thus, post-accession migration had even more dramatic consequences. For example, over 15 per cent of the Romanian population lived abroad in 2015, with around 25,000 in Sweden (IOM, 2015). According to recent estimations from Statistics Sweden, almost 19,000 children and young people from Romania and Poland reside in Sweden with their families. Thus, similarly to the UK, Ireland and Norway, post-accession migrants' tendency to settle can now also be observed in Sweden (SCB, 2015). ${ }^{4}$

Because Sweden is still a new destination country for mobile intra-European workers, there is very limited research on transnational caregiving in the Swedish context. What is important to emphasize in relation to the transnational caregiving within the intra-EU space is that it takes place between welfare regimes and family policy systems, which vary significantly regarding their degree of supportive care policies and structural implications for care arrangements and obligations. In countries such as Poland and Romania, with a long history of universal state social policies since the collapse of communism, their welfare regimes are driven by the implicit familialism ideology (Jarovnik, 2014; Basten and Frejka, 2015), which is characterized by a strong reliance on care provided by family and their kin. Despite the socialist legacy of gender equality (at least at the policy level), the Polish and the Romanian welfare states suffer from economic and institutional inconsistencies. With low public support for families and meager provisions for child allowances, much greater responsibility is transferred on families and especially on women for their own welfare and care obligations both inside and outside the family circle (Jarovnik, 2014; Basten and Frejka, 2015). When parents from Poland and Romania, where only the poorest are eligible for family provisions, migrate to Sweden for work (and eventually decide to settle), they carry with them an attitude that "the State is not there to serve the citizens" (Runfors et al., 2016, p 8) and they must rely on themselves for subsistence and care. Simultaneously, migrants encounter a society of a quite different nature in Sweden, which is a social democratic universal welfare state with active defamilialization of care services reliant on public child care and universal child benefits (Suwada and Plantin, 2014). More importantly, the Swedish welfare state strives to facilitate the non-dependency of family members on each other by assisting those in need with state support (Runfors et al., 2016).

When the lives of the EU migrant workers and their families are compared in their origin and destination countries, they are shaped by the contrasting welfare, family and gender regimes to a significant extent. While the logic of autonomy and self-reliance seem to be a common ground for the Romanian, Polish and Swedish welfare systems, the underlying premises of nondependency in these societies are rather different. As for their self-reliance strategies, Poles and Romanians must work against the backdrop of low welfare state spending and the implicit familialism ideology in CEE. In contrast, the non-dependency logic in the relationship between the citizens and the state in Sweden relies on "a high trust in the welfare system" (Runfors et al., 2016, p 4). Even though the general welfare system and especially family policies discussed here might have a limited role on the initial decisions to migrate, they seem to increase the value of employment in Sweden in the long run and potentially play a crucial role in deciding where to settle with the family.

\section{Family obligations across European borders: a theoretical outline}

As already indicated, research on family obligations derives to a large extent from the seminal works of Finch $(1987,1989)$ and 
Mason (1996), who explored the negotiations of responsibilities and commitments within families in the UK from a variety of angles. The primary concern in this research was to study the ways in which the meaning of family is constructed through a dynamic process of giving, receiving and negotiating support and assistance among adult relatives. The most significant contribution of this research is to our understanding of (non)supportive relations within families as manifestations of their responsibilities developing over time. In many of their works, Finch and Mason have developed the notion of family obligations in a dialog with scholarly feminist work on care that urged for acknowledgment of care and caring as "the invisible, often completely unpaid and underestimated, work by women that generates well-being in other people" (Anttonen and Zechner, 2011, p 27). With strong connections to the feminist intellectual tradition, Finch and Mason approach family obligations and care from somewhat different angles. The novelty of these approaches stems from the assumptions that: (1) family obligations are not determined either structurally or genealogically; (2) supportive relationships within families can neither directly be derived from normative rules of what kin should do for each other. Instead, following Finch (1987, 1989) and Mason (1996), the core family obligations are found in how family members negotiate their commitments and exchange support within a broader socio-cultural context over time. These negotiations, as Mason (1996) emphasizes in her work, allow people to make active choices regarding their various responsibilities for other family members. These choices, although interwoven with various socio-structural constraints, are based on the quality of relationships shared by the specific relatives, the emotional contacts they have established or happened to lose over time, and on the moral character of these relations.

In critically engaging with feminist theories on care, Mason (1996) argued that to conceptualize caring within families in sociological terms, we need to include moral and emotional dimensions into analyses of how individuals within families and their kin negotiate and commit themselves to care. In her relational perspective on care, Mason aims to move beyond the dominant notion of care as simply labor or simply love, which is an assumption invoked by a vibrant feminist scholarship of the 1990s. Instead, elaborating on Sevenhuijsen's and other feminist ideas, Mason (1996) develops a concept of care that considers thinking and feeling in the very activity of caring. While insisting on thinking and feelings conceived as activities, Mason (1996, pp 27-32) coins the concepts of sentient activity and active sensibility as two closely related elements of caring. Sentient activity identifies such caring practices as "noticing the needs of specific others", "interpreting individual preferences or moods", and "worrying about the well-being of particular family members". Active sensibility is the activity of "accepting and taking responsibility for others" and "the acknowledgment of commitments to significant others". By introducing the analytical tools of sentient activity and active sensibility, Mason invites us to approach the issue of care within families as a multidimensional concept, where pure exchanges of material and practical support are closely intertwined with thoughts and feelings that are inherent components of both "the activity of care and the relational process through which it develops" (Mason, 1996, p 26).

Our analysis evolves from Finch (1987, 1989), Mason (1996) and other scholars' work on family obligations, which we elaborate on further by examining how family obligations are enacted in transnational families. This is done within the context of largescale intra-European migration, particularly Polish and Romanian mobility for work in Sweden. We specifically address parental care concerns when parents decide to migrate while their children, at least initially, stay in their home countries in the care of other family members, such as a parent, grandparent, or on their own in some cases. Interestingly, while Finch and Mason did not confine their analyses to family obligations towards younger children or to caring and migrant families, their concepts became notably important in the scholarship on transnational families. Running parallel to other influential studies on parenting and particularly transnational parenting (Carling et al., 2012; Miller, 2017), researches on transnational families and care by Baldassar (2007), Baldassar and Merla (2013) and many others actively applied Finch's (1989) terminology on various types of family support to describe them as types of transnational care in all permutations as exchanged between family members across distance and over time.

Thinking of families in transnational terms led to an increased attempt to reconceptualize the notion of migrant families regarding the spatio-temporal dimensions of their mobile lives, transnational parenting and the mobility of care (Baldassar, 2007; Carling et al., 2012; Baldassar and Merla, 2013; Kilkey and Palenga-Möllenbeck, 2016; Merla and Baldassar, 2016). Initially, the recent conceptual development of families "living together across distance" (Baldassar and Merla, 2013, p 19) questions the normative perception about family occupying one locus of residence and about living in close geographic proximity as a necessary condition to maintain significant intimate and social ties. What comes to the fore in these studies is that mobility and absence are now an integral part of family lives. Separation and distance do not automatically lead to family disintegration or cause lack of intimacy between family members. Instead, this research strongly assumes that family and their kin constitute strong bonds and solidarity across distances by using multiple information and communication technologies and new media environments to stay connected (Baldassar et al., 2016).

In the European context, research attention on transnational family migration has emerged relatively recently, in contrast to the long-standing and ample research on transnational families and care in the Americas and the Asia-Pacific region (Hondagneu-Sotelo and Avila, 1997; Ehrenreich and Hochschild, 2003; Parrenas, 2005; Carling et al., 2012). The relevance of the transnational lens in an expanded Europe has been emphasized because of the increasing East-West mobility within the EU after 2004 (White, 2010; Friberg and Eldring, 2013; Glorius et al., 2013). In the light of the persistently celebratory policy perception of mobility as a symbol of freedom and privilege, the assumption was that labor mobility within the EU will remain circular and temporary. Researches on intra-European migrant families soon set aside these expectations by pointing out a significant shift in the strategies and trajectories of many EU workers and their families, especially in the wake of the 2008 economic crisis, which means that mobility within the EU has grown to be less temporary and seasonal (Friberg, 2012; Glorius et al., 2013; Slany and Pustulka, 2016). Instead, EU mobility has been characterized by more open-ended patterns of movements, with prolonged stays and increasing tendency to reunification and settlement in the host countries. Against this backdrop, researches have acknowledged the enabling role of geographic proximity between the home and host countries of the recent mobile workers, legal opportunities to claim EU citizenship rights and the availability of cheap travel and mobile communication creating "virtual" proximity across borders (Moskal, 2011; Slany and Pustulka, 2016; Slany et al., 2018). ${ }^{5}$

While the concept of transnationalism continues to proliferate through studies on migration, family and parenting in Europe, we agree with the growing concern among the researchers who drew our attention to "the Janus-faced nature of migration" (Kilkey and Palenga-Möllenbeck, 2016, p 339) and to the limitations of transnationalism particularly for migrants with family obligations (Evergeti and Ryan, 2011; McGhee et al., 2013; Bell and Bivand 
Erdal, 2015). Together with these and other studies, we pose several pertinent questions about the diversity and complexity of family care strategies across borders, as well as the gendered divisions in caring activities (see also Ryan et al., 2009; Bell and Pustulka, 2017; Souralová and Fialová, 2017). As Miller (2017, p 29) observed, caring activities and responsibilities have been historically considered as women's "natural capacities", which also is reflected by the fact that even today in many societies, including countries such as Sweden, ${ }^{6}$ women still mainly perform primary care for children. By acknowledging the gendered experiences and practices of care, researches on transnational parenting and care arrangements long had a prevailing interest on transnational mothering, especially on "absent mothers" and their children who were left behind (Ehrenreich and Hochschild, 2003; Parrenas, 2005; Lutz and Palenga-Möllenbeck, 2012; Ducu, 2014; Ducu and Telegdi-Csetri, 2016). Even though more recent debates on transnational parenting also include fathers and their increasing care responsibilities toward raising and nurturing children, the emphasis is still on their work and breadwinning role as migrants rather than on their experiences as migrant fathers. Thus, a prevailing perception is that migrant mothers' care towards children is still conceptualized in terms of their emotional closeness and love, while father-children relationships are more often described in terms of authority and emotional distance (Ryan et al., 2009). By voicing an important critique against binary and rigid views on parenting and care in transnational families, we align with researchers such as Bell and Pustulka (2017) and Souralová and Fialová (2017, p.170) who called for "researching the diversity of roles which men and women play while being breadwinners and caregivers, economic and emotional providers at the same time."

While gender is still a signifying feature of the cultural ideas and normative practices of transnational care arrangements, it is not a singular differentiating factor in the experiences of transnational care and family obligations. There is a continuing debate within a vast scholarship on transnational families pointing out that class and global social inequalities, also in the context of the EU, pose significant challenges to transnational care circulation (Carling et al., 2012; Perrons et al., 2010; Faist, 2014; Kilkey and Palenga-Möllenbeck, 2016). The central arguments of these researches align with the key theoretical and methodological assumptions of our own study; i.e., mobility should not be simplistically equated with freedom and privilege for those who are mobile. For respondents in our study, mobility to Sweden in search for paid employment was caused by socio-economic inequalities. In Poland and Romania, which are both former socialist states, the introduction of market economies meant an increasing polarization within the society because of the collapsing welfare state provision for families and greater responsibilities placed on families and parents themselves for securing their own well-being. Thus, mobility within the expanded EU is still largely instigated to assure an acceptable livelihood for migrant parents and their families. The presence of children in the families is often one of the main incentives for parents to migrate; however, deciding on migration often takes place without the actual involvement of children in the hope that the need to migrate would not last too long (Friberg, 2012). Leaving children behind, even if for a short time, involves complex moral reasoning over the entitlements and obligations for those who leave and those who stay in transnational co-parenting in split households and morality-laden negotiations concerning child upbringing (Carling, 2008; Carling et al., 2012).

Thus, we utilize the conceptualization of family obligations in this study by defining care as gendered activity with sentient and sensible caring elements (Mason, 1996; Souralová and Fialová, 2017), which in transnational context is combined with various sets of moralities (Carling, 2008; Carling et al., 2012). We attempt to highlight a great number of complex and conflicting roles, as well as competing responsibilities when migrant parents negotiate their migration decisions, including motivations to pursue migration, the gendered patterns of caring shaping the migration decisions and the moral reasoning over what is the right thing to do in relation to caring for children.

\section{Data and methods}

This study is based on the analysis of 22 qualitative interviews conducted between September 2015 and January 2017 in the two largest Swedish cities, Stockholm and Gothenburg, for a broader research project, entitled Caregiving arrangements in the enlarged Europe: Migrants' parental strategies and the role of the institutional context in Sweden. One of the theoretical considerations guiding the methodological choices was a gendered perspective on care, which implied that our sample was almost equally composed of both mothers (11) and fathers (9), whom we interrogated on their gendered subjectivities and experiences of care and parental obligations. Such an approach was in line with our understanding that transnational mothering and fathering have for too long been studied through their binary roles and responsibilities. These studies failed to acknowledge the multiple caring roles taken by both migrant mothers and fathers (Souralová and Fialová, 2017).

Research participants were recruited using multiple gate-keepers, including trade union organizations, non-government organizations for EU migrants, churches and ethnic community associations, and snowball sampling to some extent. Most of the respondents were found within an increasingly booming sector of the lower paid and lower qualified jobs, with clearly gendered patterns: e.g., men working in construction and building industries, and women working in domestic work, cleaning, hotel industries, food production. ${ }^{8}$ There is a partial alignment between migrant parents' predominantly lower educational backgrounds and the lower-qualified jobs they perform in Sweden. However, we can also argue that several of their stories witness the severe deskilling among the participants because their previous longlasting work experiences and, in some cases, even higher education degrees were disregarded by their employers in Sweden. The age of the participants varied from their early 30 s to early $50 \mathrm{~s}$. At the time of the interview, three parents were divorced (all of them mothers) and most respondents had two to three children aged between 8 months to 27 years old. ${ }^{9}$ Initially, our intention was to interview mothers and fathers who were the lead movers working in Sweden on temporary contracts after 2004 (for the Polish respondents) and 2007 (for the Romanian respondents), while their families remained in the home countries. As the project unfolded, it became notoriously difficult to find migrants prepared to talk about the ongoing process of living in a split household. ${ }^{10}$ The most important criterion we employed instead was the experience of care at a distance, which could be narrated retrospectively. Thus, most of the parents we met while interviewing had already relocated their spouses and/or children to Sweden. By including both leading and joining migrant parents in our sample, we were able to achieve an important understanding of the diversity in experiences of care at a distance. Moreover, we could deepen our insight into what kinds of negotiations and moral reasoning in relation to care obligations were taking place when parents decided to migrate. In doing so, the migration decisions were illustrated from a variety of perspectives depending on whether the leading parent was a father or a mother who left their spouses and children back in their origin country, or a single mother fully dependent on other kin for care provision, or if both parents came to Sweden together. 
The interviews were thematically structured and revolved around the themes of motivations for the migration decisions, transnational configuration of the families, reasons for choosing Sweden as a destination country, previous experiences of migration, working situation in Sweden, and the formal and informal networks surrounding migration. The questions we asked during the interviews were specifically intended to invite parents' reasoning on the norms and moral codes imbued in the idea of "good" parenthood, but also in relation to the parents' capacities, obligations and negotiated commitments due to the spatial separation and multidirectional flows of care within their families. The non-static and processual characteristics of transnational family life among European labor workers in Sweden was an implicit assumption which we worked with right from the outset of the study. Thus, we asked parents to reflect upon how they imagined their migration to unfold when they decided to leave and how it may look like in the future depending on their plans for settlement.

The interviews with the parents were analyzed using the lifeline method (Davies, 1996), which is an analytic tool to illuminate mobility for work as being marked personally, as well as collectively within the multiple institutional settings in both home and destination countries. Using this method allowed us to capture different stages in the lived experiences of the European worker's families, from their decisions to migrate, caring at a distance, visits home and, for some of the families, eventual negotiations on settlement in Sweden. Focusing on decision-making, we used the categories of gender, norms and negotiations of family obligations, moralities of transnational parenting, sentient activity and active sensibility to code the material and make conceptual comparisons between the stories of different migrating parents. The care arrangements of each respondent were analyzed in a holistic and contextual manner in relation to their country of origin, gender roles, family configurations, and the formal and informal recourses they planned to activate for caregiving over time. Finally, quotations have been edited for idiomatic English to enhance their readability.

\section{Negotiating migration decisions: caring moralities, feelings, and thoughts over time}

Below we present the analysis of family obligations across borders by focusing on the negotiation of migration decisions as narrated by the migrating parents retrospectively. Our analysis is presented in three sections, which highlight the different stages in transnational family life of the European migrant parents. Using the lifeline method (Davies, 1996), we focus on the experiences of six respondents, which are both similar to and different in various ways from the experiences of other migrant parents who we have interviewed. Even so, these stories are diverse and complex in a sense that they include the narrations of two mothers, Ada and Viorica, ${ }^{11}$ who settled in Sweden with their children, and also a spouse in Ada's case. These two women were among the first European migrants who took the opportunity to search for employment in Sweden immediately after their countries, Poland and Romania, respectively, joined the EU. Other stories are of a mother and a father, Stefania and Jakub, both from Poland, who have relatives in Sweden and had visited the country many times prior to deciding to pursue a livelihood abroad. Both parents followed the strategy of "permanent temporariness" (Friberg, 2012, p 1602), which means that they basically lived with their respective families in Poland while working in Sweden. Yet another strategy was voiced in two other stories by Sorin and Olivia, both from Romania, who are the most recent European migrants to Sweden in our sample. Both respondents have very young children. On the one hand, an important difference in their experiences is that Sorin had tried to bring his family to Sweden and after struggling for survival, the family decided to live 'apart together' again. On the other hand, Olivia has the valuable perspective of a joining parent who moved to Sweden together with their first child after a longer period of living apart and after a while they had a second child.

The individual migration stories will be linked to the rest of the interviews with migrant parents and other empirical data collected for the project in further analysis. Thus, the analysis reveals the variety of strategies in deciding to migrate and multiple migration trajectories. What comes to the fore are the importance of the timing for and motivations to migration, family configurations, children's age, parental roles and responsibilities, as well as feelings and shifting moralities which illustrate a complex nature of caring that is carried out relationally and resourced from the specific national contexts in between which migration and mobility take place.

Motives for seeking a livelihood abroad. Following Brannen (2017, p 10), we adopt an approach of "historicizing family lives" when aiming to understand the motivations behind the decisions for migration within the context of post-accession Europe. Such a strategy implies that we regard decision-making as long lasting and sometimes covert processes of negotiations taking place in the socio-historical contexts in which the migrants' lives unfold. When we asked parents to recall how, when and with whom they were discussing about going to Sweden for work, it became apparent that these decisions were far from being "a one-off lifetime event” (Kilkey and Palenga-Möllenbeck, 2016, p 347), with settlement and integration as their ultimate goals. Instead, mothers, as well as fathers were involved in a complex web of interactions between the moral norms ascribed to parenting in their home societies and how they related to these norms when migration was negotiated as an option between the spouses and (or) children, and their other relatives. After experiencing a significant drop in employment rates and living standards since the post-communist transition, many people in Poland and Romania, especially those with family obligations, considered migration for work as the only viable option to secure a decent standard of living:

My husband and I lived in a small town. He worked at the bank and it was a reasonably good job. I worked at the grocery shop despite my previous education [banking and finance college]. It was extremely difficult to find a job according to my education. The incomes we earned [together] were simply not enough. (Ada, 37, 2 children, Poland $^{12}$ )

Ada came to Sweden 1 year before Poland joined the EU, in the summer of 2003. At the time, she was 25 years old, married and a mother to a son, who was two and half years old. In the small town in north-eastern Poland where Ada comes from, migration has already become what White (2011, p 16) called a common "livelihood strategy" for families with limited resources in search for a steadier or at least a better paid employment abroad. For Ada, going to Sweden was her first experience of going abroad. Despite being a dual-earning household, the young couple could not independently cover the monthly expenses for the rent of a small sublet flat and food. Their parents on both sides had to step in to support this young working family with a small child.

The prospect of a "better life" back in her home country was also a major concern for Viorica, who arrived in Sweden in 2008, roughly 1 year after Romania joined the EU. She remained a single mother with three school-aged kids without any welfare support from the Romanian state or alimony payments from her 
former husband. She mainly worried about her two older kids, 14 and 16 years of age, who were about to start high school in another town. Viorica was anxious about her poorly paid job at the milk factory, which would not pay enough to cover the costs for children to commute and "keep them at school":

If I had not gone away, I wouldn't be able to support them financially, to send them to school, to pay the rent, travels, clothes and other things that were needed. I simply could not manage all of that from my salary of 100 Euros. ${ }^{13} \mathrm{I}$ could not have managed because I did not have any kind of help from anyone. Their father never supported them financially. It was only me that could do that and no one else. (Viorica, 44, 3 children, Romania)

Acting as the "target earners" described by Friberg (2012, p 1603), Ada and Viorica imagined mobility for work as a shortterm venture to improve their lives back in their home country. Nevertheless, mobility for work to another country involved several financial investments, saving up the money for the trip, for the immediate expenses upon the arrival and for all other unpredictable situations that could arise. Keeping in mind that most of the families who considered migrating lacked the economic resources to begin with, investing in migration was a risky enterprise. Seen in this light, Ada and Viorica's decisions to migrate were precarious at the time because the jobs they both were offered in Sweden, as a cleaner and a cook, respectively, were insecure and the immediate financial benefits they could bring were not definite. Simultaneously, their motivations to migrate represent an example of transnational motherhood in breach with the traditional depiction of migrant women as being dependent and playing mainly supportive roles to their spouses (Ryan et al., 2009). Conversely, mothers' search for a better-paid job abroad can be described as an active response to the needs of the family. Their migration was driven by a feeling of responsibility to be able to pursue a decent life for their family against the backdrop of poor state support for families with children; i.e., this is a clear example of caring as active sensibility in Mason's (1996) terms.

Among the parents we interviewed, they commonly did not announce their departure to any authorities at home or their arrival to any corresponding entities in Sweden. The ideology of the post-socialist states, including Poland and Romania, promoted the non-dependency of its citizens on the state support, and to some extent, migration has been stipulated by these states as the one of the most desirable ways to earn subsistence and to provide care for their dependents, including children and elderly parents (Ducu and Telegdi-Csetri, 2016; Slany et al., 2018). Having internalized an attitude of self-reliance from these postsocialist states and their formal institutions, migrant parents had low expectations towards the EU and the Swedish mobility frameworks. Instead of looking for formal employment, for instance, they mainly used close or more distant personal ties and networks to enter the labor market:

I already had a job offer when I came to Sweden. I went straight to work for a company [...]. I was lucky because I worked with a few other people from Romania and we spoke our own language, but otherwise it would have been really hard. (Viorica, 44, 3 children, Romania)

Hoping to be able to earn money as soon as possible to renovate her house back in Romania and finance her children's education, Viorica entered the Swedish labor market as a posted worker ${ }^{14}$ with help from her cousin who worked for the same company. She was sent to Sweden to work in a fast-food chain restaurant while being employed by a company in Romania. As several other researchers have emphasized (Ryan et al., 2009; Evergeti and Ryan, 2011; Anghel, 2013), migrants are prone to tapping into ethnic and kinship networks as their most valuable support resource during migration. Important though is to acknowledge a dynamic nature of the mobile workers' transnational networks. In the study of the Polish workers in Norway, Friberg argued that "social networks and the support which migrants can derive from them must be differentiated temporally" (Friberg, 2012, p 1592). While migrants' family and kin support play a primary role at the initial stage of migration, over time, it is the weaker ties in the host country that gain more importance, by providing information on the availability of jobs, for a place to stay, and more generally for socializing in a country where they do not speak the language.

In the data collected for the study, most of the parents had come to Sweden alone with an initial intention to stay a few months or the maximum of a year to earn money to send back home to their families. This strategy of an open-ended migration was described as "just try and see what will happen" (Garapich as cited in Bell and Bivand Erdal, 2015, p 93) was widespread among the post-accession Polish migrants to the UK, Ireland, and Norway (Ryan et al., 2009; Friberg, 2012; McGhee et al., 2013). Like many other leading migrants from both Poland and Romania, Sorin expressed this attitude while discussing his move to Sweden with his family back in his home country:

To be honest, I did not think about how long I will be staying here, I did not think about bringing my family here either. I just thought that I will be here for some time, may be a year, and then go back to Romania (Sorin, 30, 1 child, Romania)

For Sorin and several other fathers in our sample, coming to Sweden was not his first episode of working abroad. He had been working on sporadic construction jobs abroad a few years before Romania joined the EU. After almost 4 years in Greece and a few months in Norway, he returned to Romania in 2011 and started a family:

A Romanian for whom I was working before [in Romania] called me and asked me to come [to Sweden]. I really don't know why I decided to come here because I had some offers in Germany as well. (Sorin, 30, 1 child, Romania)

For Sorin, who was soon to become a father, migration per se became an appropriate strategy for leaving his home country due to a widespread culture of migration. Young couples in CEE, including Ada and Sorin's families, have usually experienced higher dependency on their parents' support for extra money at the end of the month, for a place to stay or for a helping hand with raising their small children. Many of Sorin's school friends from the same village in Romania were also working abroad, and one of them worked in Stockholm. Therefore, Sorin longed for an independent family life like many other parents-to-be, which in times of economic hardship often pushed them to consider looking for a job abroad as a way of taking responsibility for their own family (Bell and Pustulka, 2017).

When fathers migrated, they left behind their women and children, who often had to accept migration as a necessity to be endured for the sake of the long-term returns it might bring in the future. However, wives did not passively comply with their husbands' departure. Similar to the findings in Ryan et al. (2009), White (2010, 2011) and Slany et al. (2018), the remaining mothers in our sample also took an active role in planning the family's migration strategy. Mothers were certainly the ones to initiate (or in some cases to put a veto on) the future relocation of the entire family to Sweden. One of our respondents among the recently arrived migrants to Sweden is Olivia. She initially remained in Romania with her two-year-old son while her husband was recruited for a construction job in Sweden, which 
was quite similar to the one he had in Romania, yet with much higher income:

[...] like any other decision we discussed together [an offer to go to Sweden] and we knew that regardless of what decision we will take [we]would regret it later. We had a child [...]. He was two years and a few months old when we made the decision that my husband should leave. It was not easy, but we decided anyway. [...] Honestly, I thought that it is better for him to experience it, to test it. I sent him to test the ground and we said that if it was OK, then we will come as well. (Olivia, 34, 2 children, Romania)

Olivia's husband joined a group of other Romanian construction workers who were settled in Stockholm. He hoped to get their support to establish himself in Sweden and then bring his family along. Meanwhile Olivia had to manage her life with a small child while working:

When I remained alone with the child, I tried to manage it on my own, but it was tough to juggle work and a child. [...] We had our own apartment, but it was not thoroughly renovated, so I stayed with my parents instead. Since we were living with my parents, we didn't really take care of [our own housing]. We were working and our only task was related to our child. All of us were taking care of the child. (Olivia, 34, 2 children, Romania)

Relying on grandparents for care and support in the home country seems to be an essential part of the livelihood strategy within transnational families, especially if both spouses have a job to pursue at different ends of the transnational field. However, it would be simplistic to consider family-led migration only within the traditional nuclear structures. Grandparents can also be significant in facilitating their children's migration strategies:

My father was working [in Sweden] on sporadic construction jobs. I joined him to help him out. At that time Poland became an EU member and I saw a chance to establish myself in the labor market. I started my own small company to test how things work out. (Jakub, 48, 3 children, Poland)

Jakub's first trip to Sweden was as a teenager in the 1980s, when he visited his aunt on the mother's side. When he joined his father in an attempt to get work in Sweden, he had his own family with two kids aged 10 and 6 years old, and a newly built house, in which they just began to settle. Simultaneously, his office job at a refinery was strenuous, involving long and frequent travel for many days per month away from his family and small kids. Having been helped by his relatives in Sweden to establish a private company registered in Poland, Jakub initially worked in Sweden as a self-employed construction worker. As a livelihood strategy, it was a very common arrangement among many male migrants from Poland, Romania and other new EU member states, who performed various construction jobs for the private households in the wealthier EU countries (Perrons et al., 2010; Faist, 2014). As a self-employed worker, Jakub did not have any rights to social protection or welfare benefits from the Swedish welfare state. Nevertheless, he and other fathers narrated their decisions to migrate more as a "choice" rather than a "necessity", because being absent from home and earning a living for a family corresponded well with "their traditionally gendered absence and provisions-oriented fatherhood" (Pustulka et al., 2015, p 124).

Migration decisions through the gendered lens. As hinted above, the moral negotiations which parents have been involved in while going abroad on their own and leaving children and spouses at home are clearly gender-marked. Even though both mothers and fathers considered migration for work as something that Finch would designate as "an unavoidable course of action" (Finch, 1987, p 165), something they were obliged to do to provide for their families, more common for mothers was to describe their departure as separation from children, consonant with emotions such as "suffering", "crying", "guilt" and "worries":

It was very hard, the moment of separation, [the children] cried a lot after me even if they accepted the situation. They cried a lot. (Viorica, 44, 3 children, Romania)

Fathers in our sample, on the other hand, tended to downplay their own feelings at the moment of departure. Similar to a neighboring example of fathers migrating from Poland to Norway and Ireland (Bell and Pustulka, 2017), they did not perceive their absence as contradicting the traditional understanding of their gender roles in their home countries. Partly it is because prior to mobility to Sweden, many fathers have been working far away from home within their home countries and some have already had migration experience. In both cases, they normalized the separation as something that breadwinning fathers are supposed to go through:

It was not easy in Poland [before I left]. In my previous job I was not at home that much except that I came home every night and slept until the morning when I left again. [If I would continue working like this] I would not be able to take two weeks 'free time' to spend with my family [as I do now]. (Jakub, 48, 3 children, Poland).

Jakub, who is a 'settled in mobility' migrant, works in Sweden for a month or two, and then goes home to Poland for a two-week period. Opening his own business in Sweden was a brand-new experience. With the growing demand for household construction services in many European countries, his customers' circle grew steadily wider and after commuting for a while, he began to realize that his new work situation might involve changes for the family as a whole:

In the beginning, I did not plan to work in Sweden for a long time. After I opened my own company, we talked at home on how things would look like with me commuting to Sweden. We even thought that my wife and kids would move to Sweden together with me at some point. However, it was my older son and I who wanted this to happen. My wife and my daughter were less enthusiastic about this idea. [...] I think it was because they were afraid of the changes it would entail for us as a family and for the new language. [...] So even if I did not plan to stay long in Sweden, the time passed, I had customer after customer and now it has been almost ten years since I first came here to work. (Jakub, 48, 3 children, Poland)

Once having started his migration journey out of a commitment to help his father, Jakub gained confidence and became the owner of a small building company, which secured his role as breadwinner for his family living back home in Poland. However, assuming "a free-flowing attitude" (Bell and Bivand Erdal, 2015, p 93) was much easier when it came to his job than in relation to his role as father. The task of taking responsibility for the wellbeing of the family had obviously legitimized his absence due to the frequent trips between Poland and Sweden. The longer he stayed in this situation, the more he started to reflect on his role as a father, especially in relation to his third child, his son, who was born during the decade that Jakub commuted between the two countries: 
[When I go home] we talk about everything, and sometime we need to talk more about children. I must say that we do not really have any big issues to deal with. Sometimes, my wife is complaining about the younger son, so I need to take care of it. [...] It is just that he listens to me more sometimes, it relates to everyday things like cleaning his room or doing his homework. [...] The younger son needs me more, I suppose. (Jakub, 48, 3 children, Poland)

Jakub's thoughtfulness about his younger son's needs speaks to the fact that migration is also marked by emotions and uncertainties, as well as changing anticipations of the future depending on how migrants see their former decisions to migrate in the light of the present. After having commuted between two countries for a whole decade, Jakub felt pulled in different directions between a rather successful business in Sweden and his longing to be together with his family back in Poland.

The experience of leaving families behind endowed Jakub and other migrants in a similar situation with moral obligations as well (Carling, 2008). By locating transnational parenthood within different sets of moralities, Carling et al. (2012, p 206) reminded us that "by virtue of being migrants", parents feel a strong personal commitment for the well-being of those left behind:

You can imagine it was hard at the beginning. My wife was few months pregnant then and it was very hard [to leave]. Especially for her because she was staying alone in the town where we started our life together. (Sorin, 30, 1 child, Romania)

However, using the concept of care as a sentient activity to describe the worries and longing for their families expressed by both Jakub and Sorin speaks against the gender essentialism characterizing much of the research on transnational fatherhood. As Souralová and Fialová (2017) noted, an important bias perpetuated in this research is in the description of migrating fathers as authoritative family figures who were missed less than migrating mothers. Given an opportunity to talk not only about their breadwinning responsibilities, Jakub, Sorin, and other fathers also underlined the importance of close emotional relationships with their children and wanting to spend more time together.

While we agree with Souralová and Fialová (2017, p 170) on the need to abandon "false contradictions" between transnational motherhood and fatherhood, we continue to argue that maternal and paternal migration strategies and care are still formulated along the lines of the persisting gendered differences. For instance, fathers rarely reflected upon the timing for migration as something that should be attuned to the children's age or their ability to manage things on their own. Neither did they express any wariness when it came to the everyday arrangements of family life while they were away. Fathers commonly regarded migration for work as a choice they made against the backdrop of the available employment, even if uncertain, but also perceiving themselves as "the secondary" or "supporting" (Miller, 2017, p 155) but not the primary carer for the children and for the home.

Conversely, mothers would frame their decisions to migrate as a "necessity", "risk taking" or "taking responsibility for the temporary economic difficulties" in the family. Stefania's story is a good example of this last motivation to go abroad. Similar to Jakub, but differing from other parents whom we spoke to, her departure from Poland lacked a symbolic meaning in her biography. Stefania had relatives living in Sweden for a long time, and had visited the country many times prior to beginning a working life in Sweden. Moreover, comparable to Jakub and Viorica, Stefania's migration for work coincided with her children becoming teenagers, who were "mature enough to manage things on their own". Before she became a mother, she ran a small catering business of her own in Poland. However, after giving birth to two sons, she closed her enterprise and became a housewife. She was supported by her husband for almost 15 years. When both of her children grew older, Stefania could finally resume her working life. When we met her for the interview, she had been commuting to Sweden every second week for the last 2 years to work in a cleaning company owned by another Pole:

We have never felt that we were short of money. It's simply sometimes there are tougher periods [...] If my children were small, I would never decide to work in these conditions, but they are big enough now and they understand why I must work [in another country]. (Stefania, 38, 2 children, Poland)

Migrant parents, especially mothers, often brought up the issue of their children's age when they recalled their initial discussions on leaving to work in Sweden. As observed elsewhere, when children are young in Poland and Romania, it is the mothers who are expected to stay home and take care of them (White, 2010; Bell and Bivand Erdal, 2015). In many of our interviews, it transpired that being at a distance from their younger children is an emotional experience for fathers and mothers alike; however, it is mainly mothers who speak about their children's age in relation to how much "mental work" of care (Miller, 2017, p 15) they would need to invest if caring activities are delegated to someone else when they are away. Before Ada could leave for Sweden, she had to negotiate her "licence to leave" (Baldassar, 2007, p 393) not only with her husband, but also with her parents and in-laws, whose daily care for a small child was essential for Ada to make her decision on migration. As a single mother and primary carer, Viorica had to negotiate her departure with her older son who would perform the role of guardian over his two younger sisters with the help of Viorica's elderly mother occasionally. Worrying about the well-being of their kids, migrant mothers' care actions were neatly "orchestrated" and "organized" in Mason's (1996) terms as both sentient activity and active sensibility.

Negotiating "good" parenthood. Apart from the fact that mobility for work can be regarded as an important self-reliance strategy, both mothers and fathers in our study underscored that their migration decisions were driven by the moral responsibilities that they ascribed to "good" parenting. In the context of the post-socialist space, parents were expected to safeguard their children's education and good up-bringing (Moskal, 2011; Ducu and Telegdi-Csetri, 2016), despite their own hardships during the socialist times. Thus, by striving to be "good" parents, migrant parents felt both an economic and moral commitment to "provide", "to improve the life chances for their children" and to make sure that their "children get everything they needed":

To be a good parent, you need to do everything you can so that your child would have a better life as you once could enjoy [...] I had to work to study further after finishing school because my mother told me that she did not have enough money to support my studies. To be a good parent means that you must create possibilities for your children by making things accessible for them, letting them concentrate on the things they like to do, so that they can develop their talents and formulate an aim to strive for in life. (Ada, 37, 2 children, Poland)

To achieve such an intensive parental engagement against the backdrop of the weakening state and social support, Ada had to migrate to be a "good" mother. At the same time, Ada, as well as Viorica and other mothers taking a lead as migrants, were 
painfully aware of the discourse "on absent mothers" and "children left behind" (Lutz and Palenga-Möllenbeck, 2012; Ducu, 2014; Raluca, 2015), which blamed them for causing suffering and frustration to their children. Recalling her own departure and absence from Poland, Ada is eager to underline this point:

I was perceived as a normal mother. I worked in Sweden for my child, for myself as well, but mainly to meet the needs of my child, as most of other parents do. Everybody knew that I had to go away and I did it for the family, I did not disappear and leave my son behind. (Ada, 37, 2 children, Poland).

At the time of the interview, Viorica had managed to relocate all three of her children to Sweden. She is very proud of her achievement. As Carling (2008, p 1461) convincingly argued, being able to facilitate migration for own children (and other relatives) can be regarded as "a source of personal gratification, pride and social prestige" in a wider society:

I am happy because I have three kids. It has been and it is still very hard to be a mother when you are alone, but it makes me happy that the kids are thankful and it makes me feel stronger. I was able to help them with their lives and to offer them a road to go forward. (Viorica, 44, 3 children, Romania)

The notion of "good" parenting is also strongly present when Sorin remembers how his life changed when he became a father just few months after arriving to Sweden. Sorin's family obligations expanded beyond the responsibility to provide for his family financially. His care towards his newborn son assumed the elements of both sentient activity of worrying and planning for bringing his family along to Sweden, as well as an active sensibility of commitment to be a good father for his first child:

[...] Your life changes completely when you become a parent. I feel sometimes as a child myself, but it is changed now. [...] I do not think much about myself anymore. I mostly think about him, I do all these things [working in Sweden] for him. But just because I am sending them money, it doesn't mean I am taking care of them. (Sorin, 30, 1 child, Romania)

Sorin's emotional expression on being a father at a distance reflects very well the effect of migration through which "(migrant) men are made into (transnational) fathers", especially "in terms of their reflection on performing their own roles" (Souralová and Fialová, 2017, p 167). His major dilemma was that after having tried to live together with his wife and a toddler in Sweden, they had to separate again because his income in Sweden was not stable enough to support all three of them living together.

Thus, many parents emphasized their concerns about maintaining a physical co-presence as a family in addition to the financial, moral and emotional aspects of performing "good" parenting. In 2013, Olivia and her son joined her husband in Sweden after he had been in the new country for one and half years. Similarly to other women who accompanied their husbands after some time living separate lives in different countries, Olivia admitted that the most important thing for her was to be together as a family:

We decided that my son and I will join my husband when we can have our own place here in Sweden. We arrived when we were sure that we could stay all together. It would have been too difficult to share the apartment with other families in the same place. It would be too complicated because of too little space. (Olivia, 34, 2 children, Romania)
The ideal of a family "staying close" and "together" is salient in many other migrants' stories as well. As Bell and Pustulka (2017) showed, many migrant fathers arrived with groups of friends to work in construction in various destinations in the rich EU countries. These groups lived in overcrowded houses or flats with very little personal or intimate space to accommodate their own families. Families with children and especially young families, such as Olivia's, Sorin's and Ada's, usually lacked the opportunity to live on their own prior to migration. In a quest for autonomy, these families were prepared to endure this separation if migration could potentially lead to a more-independent family life. However, Olivia's story confirms the observations of other researchers in post-accession migration (McGhee et al., 2013; Pustulka et al., 2015; Shmulyar Green and Melander 2016) that it was notoriously difficult for the newly arrived migrants to get their own housing and be able to pay for it, which created an important impediment for families to reunite and to start the independent life that they dreamed of.

For more recent migrants with no intention to settle, such as Stefania, the livelihood strategy of frequently commuting between Poland and Sweden is considered as "something completely normal" and "natural".

I have not experienced that my work in Sweden influences our family life. There is no big deal in me being here once a while and working [...] My husband does everything at home. (Stefania, 38, 2 children, Poland)

In contrast to many other migrant parents in our study, but also in other researches (McGhee et al., 2013), who talked about their inability to live in two places at once, Stefania feels proud that she can be a "good" mother because as a migrant, she can contribute to her family's economy on an equal basis to her husband and simultaneously be a full-time responsible parent:

We are not some kind of perfect family. We are normal. But we manage to achieve many things. [...] When I am in Poland I feel that I am one hundred per cent a mother. They have everything that they want and need. (Stefania, 38, 2 children, Poland)

Stefania simultaneously underlines the importance of organizing things in a proper way for such a way of life to be liveable. Even if caring practices in relation to children were described as shared (equally) with her husband, it was Stefania who continued to carry the overarching responsibility for them while being away:

We share the responsibility [for children], half and half, we try to take the decisions together [...]. In a sense, we complement each other. If I am not available, my husband can do things instead of me. If I am not at home when they need to decide on something, my husband calls me. (Stefania, 38, 2 children, Poland).

Another strategy to compensate the absence of a "commuting" parent exercised by Stefania, Jakub and others is to create a feeling of constant co-presence. Migrant parents in our study, like other transnational migrants described by Baldassar (2007), put a lot of time and efforts in building reliable relationships with their children by "staying in touch" despite the physical distance as their family life unfolds over time:

My children know that if they need me they can simply give me a phone call and I will be there. [...] They know that they can always trust me. In the beginning, it was not so easy; the possibilities to communicate and travel [between Poland and Sweden] were much more limited, but now there are no obstacles at all. Knowing that I am close to my family and can reach them quickly if necessary is very 
important for both me and my family. (Jakub, 48, 3 children, Poland)

\section{Concluding remarks}

The qualitative study that this article draws upon is devoted to transnational caregiving practices in the European families in Sweden as a result of the enlargements of the EU in 2004 and 2007. Due to the open door policy to mobility of labor adopted by Sweden, many men and women, who are parents, were able to migrate to find better paid jobs and provide for their families back in their home countries. In this article, our primary concern was to examine how migrant parents negotiated their migration decisions as an act of care and responsibility, but also as morally imbued obligations in relation to their children.

In this endeavor, we follow the collaborative work by Ducu and Telegdi-Csetri (2016, p 15) who expressed the need to look closely at "the fragmented life practices, here-and-now decisions, lived and done self-empowerment and networked solidarity" while doing research on transnational families in the European context, where many gradations, differences and inequalities from the former times of the East-West divide persist. In our analysis, we have presented six different cases that reflect different strategies in migration decisions and trajectories, imbued with shifting moralities, responsibilities and feelings that illustrate a complex nature of caring as a relational activity composed of material, moral and cognitive components (Mason, 1996).

Conceptualizing migration as a'livelihood strategy' (White, 2011) reveals that mobile families' decisions to migrate involve complex and dynamic negotiations over the options and resources of entire families and their kin across generations and transnational locations. While negotiating their departures, both migrant and remaining parents, as well as older children with caring obligations, had to put up with much uncertainty, which often required moral reasoning and conflicting feelings related to the suitability of such decisions in relation to the children's needs and their age. Drawing on Finch's $(1987,1989)$ and Mason's (1996) understanding that moral norms are actively negotiated and put into use in specific social contexts, we found that the concept of family obligations adds more layers of complexity when we attempt to understand how decisions to migrate are related to parental concerns on care. As migration unfolded over time, parents have justified their conduct as the most appropriate thing to do because they were committed to their families and children and invested their social reputation in being a reliable and caring parent. However, in actual practice, caring remains a gendered activity, where fathers' negotiations of their family obligations and caring practices do not mirror those of mothers' in the same ways, nor do they equally compare to the time spent on "thinking" and "orchestrating" the family's caring tasks both locally and transnationally. One of the most important paradoxes revealed by this research is that to be a "good" parent, both mothers and fathers had to migrate, which exposed their families to physical absence, distance and separation, and altered the relational dynamics between parents and children in the longrun. This observation fits well with a powerful argument put forward in the recent study by Kilkey and Palenga-Möllenbeck (2016, p 347), who argued that "the political right to be mobile is often a mixed blessing, because it is often felt to be intrinsically connected with an obligation to be mobile".

In many ways, one of the contributions that this article makes is to provide a critical analysis of changing geographies of mobility and migration within the European space, where studies on mobility to Sweden are still very limited and mainly focusing on the labor related issues of migration. Another contribution that we make is to a sociological conceptualization of migration decision-making within the European mobility space as an essential moral, emotional and relational context in which caring as sentient activity and active sensibility develops between migrating parents and their children under significant structural constraints. In doing so, we call for further research on situated transnationality where the'free movement' within the $\mathrm{EU}$ is exposed to further scrutiny beyond celebrating the right to move freely and towards the study of important implications that free EU mobility spaces create for the lived realities of mobile family practices and obligations.

Received: 30 October 2017 Accepted: 27 February 2018 Published online: 20 March 2018

\section{Notes}

1 This article draws on the research project Caregiving arrangements in the enlarged Europe: Migrants' parental strategies and the role of the institutional context in Sweden (2014-0731) funded by the Swedish Research Council for Health, Working Life and Welfare from 2015 to 2018. The people involved in the project are the authors, who are the principal investigators, and the leader of the project, Prof. Ingrid Höjer.

2 Sweden, the UK, and Ireland continued their open-door policy even during the 2007 wave of accession; therefore, they did not apply any transition rules towards migrants from the two new EU countries.

3 When we wrote this article in 2017, the UK, which was one of the few EU countries that initially fully embraced the EU enlargement to the east in 2004 and subsequent years, has initiated a two-year process of leaving the $\mathrm{EU}$ as a consequence of the Brexit vote in the UK in June 2016.

4 The picture of mobility of workers between the EU countries, and from Poland and Romania to Sweden is incomplete if we consider only those who plan to reside in the country for more than a year because these workers are considered in the official statistics of Sweden. Among the mobile worker flows, a considerable number work on postings and on seasonal contracts (EC, 2011), which basically excludes most of the self-employed mobile workers who work in Sweden on a weekly or monthly basis and also those who work without a formal contract (Likic-Brboric et al., 2013).

5 These opportunities have been significantly endangered due to the Brexit vote in the UK where most of the recent EU mobile nationals, primarily from Poland, have chosen to search for a job and eventually settle. Poles are now the largest minority residing in the UK, having taken the lead from the minority with an Indian background (BBC, 2016).

6 Advertisements for Sweden abroad on an official website (Sweden.se) presents the country as "a gender equality role model"; however, with some "room for improvement".

7 Altogether we interviewed 20 migrant parents. Among them there were two female migrants whom we interviewed twice, two couples where husband and wife were interviewed separately, one female respondent was interviewed in the presence of her husband, and one male respondent in the presence of his wife. One of the 22 interviews was a pilot interview conducted with a female migrant from Latvia. Due to the rich quality of information, we included this interview in our sample. The interviews lasted from 1.5 to $2.5 \mathrm{~h}$. They were conducted mainly in the respondents' native languages with the help of interpreters and transcribed verbatim. Apart from qualitative interviews with migrant parents, we have also collected 10 interviews with the frontline staff at the Swedish Work and Insurance agencies, tax authority, representatives of the trade unions with the largest concentration of workers from Poland and Romania, but also employers, non-government organizations, and gatekeepers at the ethnic organizations. Another important source of empirical material is comprised of documents, including the EU and the Swedish national regulations on the issues of mobility, family policies and social security for mobile workers who are parents.

8 In Sweden, as in the rest of the EU countries, the majority of the intra-European labor migrants can be found within these economic sectors, which are often characterized by a larger degree of informalization with insecure, atypical and underpaid jobs (Fribeg, 2012; Likic-Brboric et al., 2013).

9 The age for the respondents and their children corresponds with the point in time when the interviews took place and not when the parents migrated to Sweden.

10 The recruitment of the respondents for the study was time consuming and to some extent inhibited by the insecurity of many potential respondents about their migrant status in Sweden because they all had experienced or still worked in Sweden on semilegal contracts and thus were hesitant to participate in the research.

11 All respondent' names used in the article are fictional. 
12 Each quotation is followed by the anonymized name of the respondent, their age, number of children at the time of the interview and the country where they came from.

13 In 2008, a salary around 100 Euros would be a common level of income for those employed in menial jobs, including the agricultural sector. However, this money was considerably devalued during the economic crisis in Europe because of the rocketing prices and expenses for the most ordinary consumption products and needs.

14 As a category of mobile EU workers, posted workers were not the primary focus in our study. For more on the legislation and the situation for posted workers in Sweden, see Thörnqvist and Bernhardsson (2015)

\section{References}

Andersson L, Hammarstedt M (2011) Inkomst och yrkesposition bland invandrare från de nya EU-länderna [Income and occupational position among migrants from the new EU member states]. Èkon Debatt 40(2):50-58

Andrén D, Roman M (2014) Should I stay or should I go? Romanian migrants during transitions and enlargements. IZA Working paper 8690. Online publication. December 2014. http://ftp.iza.org/dp8690.pdf.

Anghel RG (2013) Romanians in Western Europe. Migration, status dilemmas and transnational connections. Lexington Books, Lanham

Anttonen A, Zechner M (2011) Theorizing care and care work. In: Pfau-Effinger B, Rostgaard T (eds) Care between work and welfare in the European societies. Palgrave Macmillan, Basingstoke, pp 15-35

Baldassar L (2007) Transnational families and the provision of moral and emotional support: the relationship between truth and distance. Identities 14 (4):385-409

Baldassar L, Merla L (2013) Migration and the circulation of care: understanding mobility and absence in family life. Routledge, New York

Baldassar L, Nedelcu M, Merla L, Wilding R (2016) ICT-based co-presence in transnational families and communities: challenging the premise of face-toface proximity in sustaining relationships. Glob Netw 16(2):133-144

Basten S, Frejka T (2015) Fertility and family policies in Central and Eastern Europe. Barnett Working papers. Online publication. February 2015. https:// www.spi.ox.ac.uk

Berg L, Spehar L (2013) Swimming against the tide: why Sweden supports free labour mobility within and from outside the EU? Policy Stud 34(2):142-161

Bell J, Bivand Erdal M (2015) Limited but enduring transnational ties? Transnational family life among Polish migrants in Norway. Stud Migr 3(157):77-98

Bell J, Pustulka P (2017) Multiple masculinities of Polish migrant men. Norma 12 (2):127-143

Black R, Engbersen G, Okólski M, Pantîru C(eds) (2010) A continent moving west? $\mathrm{EU}$ enlargement and labour migration from central and eastern Europe. Amsterdam University Press, Amsterdam

Brannen J (2017) Approaches to the study of family life: practices, context and narrative. In: Česnuitytė V, Lück D, Widmer ED (eds) Family continuity and change. Palgrave Macmillan, Basingstoke, pp 9-31

British Broadcasting Corporation (BBC) (2016) Poland overtakes India as a country of origin. UK statistics show. www.bbc.com

Carling J (2008) The human dynamics of migrant transnationalism. Ethn Racial Stud 31(8):1452-1477

Carling J, Menjivar C, Schmalzbauer L (2012) Central themes in the study of transnational parenthood. J Ethn Migr Stud 38(2):191-217

Davies K (1996) Capturing women's lives: a discussion on time and methodological issues. Women Stud Int Forum 19(6):579-588

Delmi (2016) Migration to Sweden in Figures. http://www.delmi.se/migration-isiffror\#!/ursprungslander-for-invandring-till-sverige-2000-2014

Ducu V (2014) Transnational mothers from Romania. Rom J Popul Stud $1: 117-141$

Ducu V, Telegdi-Csetri A (eds) (2016) Managing difference in Eastern-European transnational families. Peter Lang GmbH, Frankfurt

Dølvik E (2013) European movements of labour: challenges for European social models. In: Jurado E, Brochmann G (eds) Europe's immigration challenge: reconciling work, welfare and migration. Tauris, London, pp 33-58

Ehrenreich B, Hochschild AR (eds) (2003) Global women: nannies, maids, and sex workers in the new economy. Metropolitan Books, New York

European Commission (EC) (2011) The end of transnational arrangements for the free movement of workers on the 30th of April 2011. European Commission Press Release. Online publication. 28 April. www.europa.eu

Eurostat (2011) Migrants in Europe: a statistical portrait of the first and second generation. Eurostat Statistical Books, European Union

Evergeti V, Ryan L (2011) Negotiating transnational care practices among migrant families. In: Kraler A, Kofman E, Kohli M, Schmoll C(eds) Gender, generation and the family in international migration. Amsterdam University Press, Amsterdam, pp 354-372

Faist $\mathrm{T}$ (2014) On the transnational social question: how social inequalities are reproduced in Europe. J Eur Social Policy 24(3):207-222

Fihel A, Kaczmarczyk P, Stefańska R (2012) Recent trends in international migration in Poland. Cent East Eur Migr Rev 1(1):69-90
Finch J (1987) Family obligations and the life course. In: Bryman A, Bytheway B, Allatt P, Keil T (eds) Rethinking the Life Cycle. Macmillan Press, London, pp 155-169

Finch J (1989) Family obligations and social change. Polity Press, Cambridge

Friberg JH (2012) The stages of migration. From going abroad to settling down: post-accession Polish migrant workers in Norway. J Ethn Migr Stud 38 (10):1589-1605

Friberg JH, Eldring L (eds) (2013) Labour migrants from Central and Eastern Europe in the Nordic countries: patterns of migration, working conditions and recruitment practices. TemaNord. Online publication. 2013:570, http:// norden.diva-portal.org/smash/record.jsf?pid $=$ diva $2 \%$ 3 A702572\&dswid $=9560$.

Gerdes C, Wadensjö E (2016) Post-enlargement migration and adjustment in a receiving country: a case of Sweden. In: Kahanec M, Zimmermann KF (eds) Labor Migration, EU Enlargement, and the Great Recession. Springer, Berlin, pp $123-138$

Glorius B, Grabowska-Lusinska I, Kuvik A(eds) (2013) Mobility in transition: migration patterns after EU enlargement. IMISCOE research. Amsterdam University Press, Amsterdam

Hondagneu-Sotelo P, Avila E (1997) I'm here but I'm there: the meanings of Latina transnational motherhood. Gend Soc 11(5):548-571

Iglicka K (2000) Mechanisms of migration from Poland before and during the transition period. J Ethn Migr Stud 26(1):61-73

International Organization for Migration (IOM) (2015) Global Migration Trends Factsheet. Online publication. 2 February 2017. http://gmdac.iom.int/globalmigration-trends-factsheet

Jarovnik J (2014) Measuring state de-familialism: contesting post-socialist exceptionalism. J Eur Social Policy 24(3):240-257

Kilkey M, Palenga-Möllenbeck E (eds) (2016) Family life in an age of migration and mobility: global perspectives through the life course. Palgrave Macmillan, Basingstoke

Likic-Brboric B, Slavnic Z, Woolfson C (2013) Labour migration and informalisation: east meets west. Int J Sociol Social Policy 33(11/12):677-692

Lutz H, Palenga-Möllenbeck E (2012) Care workers, care drain, and care chains reflections on care, migration, and citizenship. Social Polit 19(1):15-37

Mason J (1996) Gender, care and sensibility in family and kin relationships. In Holland J, Adkins L (eds) Sex, sensibility and the gendered body. Macmillan, London, pp 15-36

McGhee D, Heath S, Trevena P (2013) Competing obligations and the maintenance of physical co-presence: the impact of migration and structural constrains in post-accession Polish families in the UK. Policy Press 2(2):229-245

Merla L, Baldassar L (2016) Concluding reflections: care circulation in an increasingly mobile world: further thoughts. Rev De Sociol 101(2):275-284

Miller T (2017) Making sense of parenthood: car, gender and family lives. Cambridge University Press, Cambridge

Moskal M (2011) Transnationalism and the role of family and children in intraEuropean labour migration. Eur Soc 13(1):25-50

Olofsson J (2012) Go west: east European migrants in Sweden. Umeå University Press, Umeå

Organisation of Economic Co-operation and Development (OECD) (2015) International migration outlook 2015. OECD Publishing, https://doi.org/ 10.1787/migr_outlook-2015-en.

Parrenas RS (2005) Children of global migration: transnational families gendered woes. Stanford University Press, Stanford

Perrons D, Plomien A, Kilkey M (2010) Migration and uneven development within the enlarged European Union: Fathering, gender divisions and male migrant domestic services. Eur Urban Reg Stud 17(2):197-215

Pustulka P, Struzik J, Slusarczyk M (2015) Caught between breadwinning and emotional provisions: the case of Polish migrant fathers in Norway. Stud Humanist AGH 14(2):117-139

Raluca AA (2015) The issue of emancipation in the ease of Romanian migrant women. In: Ducu V, Telegdi-Csetri Á (eds) Managing difference in easternEuropean transnational families. Peter Lang $\mathrm{GmbH}$, Frankfurt

Runfors A, Fröhlig F, Saar M (2016) Comparative analysis of the portability of social security rights within the European Union: Estonia-Sweden case study. WSF Policy Brief. Online publication. 16 October. https://transweldotorg. files.wordpress.com/2015/11/policy-brief-portability-estonia-sweden2.pdf

Ryan L, Sales R, Tilki M, Siara B (2009) Family strategies and transnational migration: recent Polish migrants in London. J Ethn Migr Stud 35(1):61-77

Shmulyar Green O, Melander C (2016) Parenting and mobility in the EU: fathers role in doing family across the borders. Conference paper at the International Workshop on Men and Migration in Contemporary Europe, June 2016, Gothenburg

Slany K, Pustulka P (2016) Children, parents and institutions in the mobility maze Cent East Eur Migr Rev 5(1):5-12

Slany K, Slusarczyk M, Pustulka P, Guribye E (eds) (2018) Transnational Polish families in Norway: social capital, integration, institutions and care. Peter Lang International Academic, Frankfurt 
Souralová A, Fialová H (2017) Where have all the fathers gone? Remarks on feminist research on transnational fatherhood. Norma 12(2):159-174

Statistics Sweden (SCB) (2015) Barn och unga födda i Polen och Rumänien [Children born in Poland and Romania], Unpublished data from the national register on children and families in Sweden

Suwada K, Plantin L (2014) On fatherhood, masculinities and family policies in Poland and Sweden - a comparative study. Polish Sociological Review 4 (188):509-524

Thörnqvist C, Bernhardsson S (2015) Their own stories-how Polish construction workers posted to Sweden experience their job situation, or resistance versus life projects. Transf-Eur Rev Labour Res 21(1):23-36

White A (2010) Polish families and migration since EU accession. Policy Press, Bristol

White A (2011) The mobility of Polish families and the West of England: translocalism and attitudes to return. Stud Migr- Prz Pol 37(1(139)):11-32

Widding Isaksen L(ed) (2010) Global care work: gender and migration and nordic societies. Nordic Academic Press, Lund

Yeandle S (1996) Work and care in the life course: understanding the context of family arrangements. J Social Policy 25(4):507-527

\section{Data availability}

Data sharing is not applicable to this article because no datasets were generated or analyzed during the current study.

\section{Acknowledgements}

We acknowledge the support of the Swedish Research Council for Health, Working Life and Welfare research grant (2014-0731) from 2015 to 2018. We would also like to thank all the participants who generously shared their experiences of parenting across borders.

\section{Additional information}

Competing interests: The authors declare no competing interests.

Reprints and permission information is available online at http://www.nature.com/ reprints

Publisher's note: Springer Nature remains neutral with regard to jurisdictional claims in published maps and institutional affiliations.

\section{(c) (1)}

Open Access This article is licensed under a Creative Commons Attribution 4.0 International License, which permits use, sharing, adaptation, distribution and reproduction in any medium or format, as long as you give appropriate credit to the original author(s) and the source, provide a link to the Creative Commons license, and indicate if changes were made. The images or other third party material in this article are included in the article's Creative Commons license, unless indicated otherwise in a credit line to the material. If material is not included in the article's Creative Commons license and your intended use is not permitted by statutory regulation or exceeds the permitted use, you will need to obtain permission directly from the copyright holder. To view a copy of this license, visit http://creativecommons.org/ licenses/by/4.0/.

(C) The Author(s) 2018 